Jisleny da Cruz Pereira'

Marcio Roberto Silva"

Ronaldo Rodrigues da Costa"'

Mark Drew Crosland Guimarães ${ }^{\mathrm{IV}}$

Isabel Cristina Gonçalves Leite

\section{Profile and follow-up of patients with tuberculosis in a priority city in Brazil}

Programa de Pós-Graduação em Saúde. Universidade Federal de Juiz de Fora. Juiz de Fora, MG, Brasil

" Embrapa Gado de Leite. Juiz de Fora, MG, Brasil

II Fundação Hospitalar do Estado de Minas Gerais. Hospital Regional João Penido. Juiz de Fora, MG, Brasil

Programa de Pós-Graduação em Saúde Pública. Universidade Federal de Minas Gerais. Belo Horizonte, MG, Brasil

Correspondence:

Marcio Roberto Silva

Rua Eugênio do Nascimento, 610 Dom Bosco 36038-330 Juiz de Fora, MG, Brasil

E-mail: marcio-roberto.silva@embrapa.br

\section{ABSTRACT}

OBJECTIVE: To analyze the cases of tuberculosis and the impact of direct follow-up on the assessment of treatment outcomes.

METHODS: This open prospective cohort study evaluated 504 cases of tuberculosis reported in the Sistema de Informação de Agravos de Notificação (SINAN - Notifiable Diseases Information System) in Juiz de Fora, MG, Southeastern Brazil, between 2008 and 2009. The incidence of treatment outcomes was compared between a group of patients diagnosed with tuberculosis and directly followed up by monthly consultations during return visits (287) and a patient group for which the information was indirectly collected (217) through the city's surveillance system. The Chi-square test was used to compare the percentages, with a significance level of 0.05 . The relative risk (RR) was used to evaluate the differences in the incidence rate of each type of treatment outcome between the two groups.

RESULTS: Of the outcomes directly and indirectly evaluated, $18.5 \%$ and $3.2 \%$ corresponded to treatment default and $3.8 \%$ and $0.5 \%$ corresponded to treatment failure, respectively. The incidence of treatment default and failure was higher in the group with direct follow-up $(\mathrm{p}<0.05)(\mathrm{RR}=5.72,95 \% \mathrm{CI}$ $2.65 ; 12.34$, and $\mathrm{RR}=8.31,95 \% \mathrm{CI} 1.08 ; 63.92$, respectively).

CONCLUSIONS: A higher incidence of treatment default and failure was observed in the directly followed up group, and most of these cases were neglected by the disease reporting system. Therefore, effective measures are needed to improve the control of tuberculosis and data quality.

DESCRIPTORS: Tuberculosis, therapy. Patient Dropouts, statistics \& numerical data. Medication Adherence. Treatment Outcome. Epidemiological Surveillance. Disease Notification. Underregistration. 


\section{RESUMO}

OBJETIVO: Analisar casos de tuberculose e o impacto do acompanhamento direto na deteç̧ão dos desfechos dos tratamentos.

MÉTODOS: Estudo de coorte aberto prospectivo com 504 casos notificados ao Sistema de Informação de Agravos de Notificação, em Juiz de Fora, MG, no período de 2008 a 2009. Foram comparadas as incidências de encerramentos dos tratamentos de um grupo de casos de tuberculose detectadas por acompanhamento direto (287) por meio de contatos mensais com os pacientes durante os seus retornos, com as coletadas indiretamente (217) por meio do sistema de registro do município. Para comparar as proporções foi utilizado o teste Qui-quadrado, com nível de significância de 0,05 . O risco relativo foi utilizado para avaliar a razão de incidências de cada tipo de encerramento entre os dois grupos.

RESULTADOS: Dos encerramentos acompanhados, direta e indiretamente, $18,5 \%$ e $3,2 \%$ o abandonaram e $3,8 \%$ e $0,5 \%$ tiveram falência de tratamento, respectivamente. As incidências de abandono e falência dos tratamentos foram maiores no grupo com acompanhamento direto $(\mathrm{p}<0,05)(\mathrm{RR}=5,72$; IC95\% 2,$65 ; 12,34$ e RR $=8,31$; IC95\% 1,08;63,92), respectivamente.

CONCLUSÕES: Houve maior incidência de abandonos e de falências na população acompanhada diretamente que, em sua maioria, permaneceu negligenciada pelo Sistema de Informação de Agravos de Notificação. São necessárias medidas efetivas para melhoria do controle da tuberculose e da qualidade dos dados.

DESCRITORES: Tuberculose, terapia. Pacientes Desistentes do Tratamento, estatística \& dados numéricos. Adesão à Medicação. Resultado do Tratamento. Vigilância Epidemiológica. Notificação de Doenças. Sub-Registro.

\section{INTRODUCTION}

Tuberculosis (TB) is a major public health problem worldwide and requires control strategies that involve humanitarian, economic, and public health aspects. ${ }^{\mathrm{a}}$

A total of 22 countries account for $82.0 \%$ of the global TB burden, among which Brazil occupies a prominent position $\left(17^{\text {th }}\right.$ and $111^{\text {th }}$ place worldwide in relation to the absolute and relative number of cases, respectively). Therefore, the control of TB in Brazil is a priority for the World Health Organization (WHO). In 2012, 70,047 new cases were reported in the country, corresponding to an incidence of 36.1/100,000 inhabitants. ${ }^{\mathrm{b}}$ In 2011, the mortality rate was 3.1 deaths $/ 100,000$ inhabitants. ${ }^{b}$

Brazil has adopted international goals to detect $>70.0 \%$ of the new TB cases and to cure at least $85.0 \%$ of the total cases detected. According to the Millennium goals, prevalence of and mortality due to TB are expected to decrease by $50.0 \%$ by 2015 . Although the country exceeds the goal for detection, the same is not true for the cure, considering the high rates of treatment default (between 10.0\% and 12.0\%). ${ }^{\mathrm{a}}$

Sistema de Informação de Agravos de Notificação (SINAN - Notifiable Diseases Information System) is the main national instrument for collection and analysis of TB data. ${ }^{c}$ However, it has limitations that hamper the real understanding of the disease, such as underreporting, data incompleteness, and data inconsistencies related to outcomes of TB cases. ${ }^{3,9,10,13,19}$

Following the prerogatives of the Brazilian Unified Health System (SUS), decentralization of the Atenção

\footnotetext{
a Ministério da Saúde. Secretaria de Vigilância em Saúde. Departamento de Vigilância Epidemiológica. Manual de recomendações para o controle da tuberculose no Brasil. Brasília (DF); 2011.

b Ministério da Saúde. Secretaria de vigilância em saúde. Boletim epidemiológico. Brasília: Ministério da Saúde, v. 44, n. 2, 2013.

c Ministério da Saúde. Departamento de Vigilância Epidemiológica. Sistema de Informação de Agravos de Notificação -SINAN: normas e rotinas. 2. ed. Brasília (DF); 2007.
} 
Primária à Saúde (APS - Primary Health Care) is a trend resulting from the Programa Nacional de Controle da Tuberculose (PNCT - National Tuberculosis Control Program), which began in 2004. APS acts as the main entry point of patients suspected and diagnosed with TB into the health care system. ${ }^{\mathrm{d}}$ This decentralization questions how well the organizational designs and organizational practices meet the needs of health care users and addresses the specificities of the territory and the access to health care services. ${ }^{28}$ Estratégia de Saúde da Família (ESF - Family Health Strategy) has remarkably expanded in Brazil; however, its staff needs to be adequately trained in TB care because only $60.0 \%$ cases of active pulmonary disease are identified through APS. ${ }^{e}$

According to the Municipal Secretariat of Health in Juiz de Fora, there are 57 APS units in the municipality: 37 in the ESF structure, 18 in the traditional model, and 2 in the Programa de Agentes Comunitários de Saúde (PACS - Community Health Agents Program). Despite the considerable number of APS units in the city, most TB treatments occur in secondary and tertiary care centers. ${ }^{f}$ This may jeopardize the strengthening of activities to control the disease, with a focus on directly supervised treatment, also known as Directly Observed Treatment - Short Course (DOTS). ${ }^{29}$

Despite its decreased rate, the incidence of TB in the municipality exceeded the state average. The incidence rate in Minas Gerais was 26.8/100,000 inhabitants in $2005,{ }^{\mathrm{g}}$ while in Juiz de Fora, this figure was 46.5/100,000 inhabitants, corresponding to 1.7 times the state average. ${ }^{\mathrm{h}}$

The city was included among those prioritized for TB control by the Ministério da Saúde (MS - Ministry of Health) because of the high prevalence of TB cases, ${ }^{i}$ however, systematized data are scarce. Data on the TB status in Juiz de Fora are provided by the Municipal Secretariat of Health or found in scientific publications. $^{24,25,27, \mathrm{fh} h}$ Furthermore, issues related to TB control remain unresolved: Does the treatment default rate in Juiz de Fora exceed the rate recommended by MS? Is the actual treatment default rate higher than the one reported to SINAN by the municipality? Are epidemiological surveillance and APS effectively fulfilling their role in the detection and correct notification of treatment outcomes?
The objective of this study was to analyze cases of tuberculosis and the impact of the direct follow-up on the detection of treatment outcomes.

\section{METHODS}

This open prospective cohort study evaluated 504 cases reported in Juiz de Fora, MG, Southeastern Brazil, between 2008 and 2009. Juiz de Fora has a population of approximately 500,000 inhabitants; in addition, it has the second largest number of TB cases in the state and is considered to be a regional hub for disease treatment.

The incidence of treatment outcomes among directly followed up TB patients was compared with that among indirectly followed up patients using the records submitted to SINAN by the city's Department of Epidemiology. This complete record of cases confirmed during the study period was provided by the city and compared with data from the SINAN report. ${ }^{j}$ This report included data from 2008 and 2009, which was updated on July 8, 2010 and August 1, 2011, respectively. At this time, the notifications should have been completed and the cases closed.

Direct follow-up occurred in four reference health care centers in Juiz de Fora, where most treatments were performed: center 1 (inpatient and outpatient), center 2 (inpatient), and centers 3 and 4 (exclusively outpatient).

The study population consisted of prevalent and incident TB cases reported to SINAN by the city over two years, divided into two subgroups: patients directly followed up in the four reference centers until the end of the follow-up period, and patients assisted in any of the city's centers and indirectly followed up until the end of the follow-up period. Information from the records sent to SINAN by the Department of Epidemiology (DE) of the Municipal Secretariat of Health in Juiz de Fora (date of treatment initiation and outcome, among others) was used to characterize the indirectly followed up group.

The inclusion criteria were as follows: the initiation of TB treatment should have been recorded in SINAN, at least one diagnostic test confirming $\mathrm{TB}$, such as sputum smear microscopy, microbiological culture, or

\footnotetext{
d Ministério da Saúde. Secretaria de Atenção à Saúde. Departamento de Atenção Básica. Política Nacional de Atenção Básica. Brasília (DF); 2007. (Série Pactos pela Saúde, 4).

e Ministério da Saúde. Secretaria de Atenção à Saúde. Departamento de Atenção Básica. Política Nacional de Atenção Básica. Brasília (DF); 2012. (Série E. Legislação em Saúde).

f Silva ÉA. Representações sociais de pessoas vivendo com tuberculose sobre a doença e seu tratamento [dissertation]. Juiz de Fora (MG): Universidade de Juiz de Fora; 2013.

g Ministério da Saúde. DATASUS. Indicadores de morbidade: taxa de incidência de tuberculose. Brasília (DF); 2008 [cited 2013 Oct 15]. Available from: http://tabnet.datasus.gov.br/cgi/deftohtm.exe?idb2009/d0202.def

h Ângelo JR. (Re)produção do espaço urbano de Juiz de Fora - MG e distribuição espacial da tuberculose [dissertation]. Rio de Janeiro: Fundação Oswaldo Cruz; 2008.

' Ministério da Saúde. Sistema Nacional de Vigilância em Saúde. Programa Nacional de Controle da Tuberculose. Brasília (DF); 2008.

j Ministério da Saúde. Sistema de Informação de Agravos de Notificação Tuberculose - casos confirmados notificados no Sistema de Informação de Agravos de Notificação - SINAN. Brasília (DF): 2004 [cited 2013 Sept 15]. Available from: http://dtr2004.saude.gov.br/sinanweb/
} 
histopathology examination suggestive of TB (granulomatous lesions with caseous necrosis) and prospective follow-up for at least six months from initiation to termination of treatment.

All patients whose initiation of treatment was recorded in SINAN were included, and no losses or exclusions occurred.

Two structured instruments were used for data collection along with each patient's general registration form: a questionnaire with sociodemographic, clinical, and epidemiological data, which was used to interview patients undergoing treatment in the four centers where direct follow-up occurred and a structured general form to collect data on patient monthly follow-up (treatment outcomes), medical records, and additional data from the SINAN database (race, HIV test results, and others). The variables were classified into two groups: 1) sociodemographic: gender, age range, race, education, monthly household income, city of residence; 2) clinical and epidemiological: means of entering the health care system (new case or otherwise), clinical presentation, type of presumptive diagnosis, type of follow-up (direct or indirect), serological HIV diagnosis, DOTS recommendation, alcohol consumption in the last year, history of smoking, and drug use in general.

Data on DOTS and race for both groups were obtained from DE and SINAN records.

Data on education level, age, place of residence, HIV diagnosis, and gender were obtained from DE and SINAN records for the indirectly followed up group and by interviews or direct observation of medical records for the directly followed up patients in the specific case of HIV diagnosis. The health care service required proof of residence for both groups.

The directly followed up patients were systematically interviewed to obtain data on their history of smoking, alcohol consumption, and drug use. For the other patients, this information was not systematically collected by the health care services; therefore, it was used for describing the directly followed up patients but not in the comparison between the two groups.

The structured questionnaire and categories used were the same for both groups.

Data related to outcome of treatment for the directly followed up patients were obtained during the patients' monthly return visit to the health care unit and from the data recorded by DE for the indirectly followed up patients. The definition of outcome of treatment was the same for both groups and followed the MS guidelines: ${ }^{a}$ treatment default (patient was absent from medical appointment on the scheduled return date and confirmed interruption of drug therapy for at least 30 consecutive days or the patient refused to initiate treatment); cure (patient exhibited at least two negative smears during treatment, one in the follow-up phase and another at the end of treatment); transfer (patient was transferred to another health care service); death (death caused by tuberculosis after the initiation of treatment); and failure (persistent positive sputum at the end of treatment or continued positive sputum four months after the initiation of treatment).

The CAGE questionnaire (Cut down, Annoyed, Guilty, Eye-opener) was applied to assess alcohol use, which was classified as moderate (0-2) or excessive (3-4). ${ }^{5}$

The tools to evaluate drug use were previously tested for validity and reliability in two other studies: Pessoas and ATAR. ${ }^{8, k}$

Data on other sociodemographic and clinical/epidemiological variables as well as on the outcomes of treatment for the indirectly followed up TB patients reported by the city during the study period were obtained from SINAN.

The characteristics of the directly followed up patients were compared with those of the indirectly followed up patients with regard to gender, education, race, age, serological diagnosis of HIV, and city of residence. The Chi-square test was used to compare percentages. A significance level of 0.05 was considered. Missing data were not considered in the Chi-square test for these comparisons, in accordance with previous studies. $^{24,1}$

Descriptive statistical analyses of the clinical and epidemiological characteristics of the directly followed up population were conducted.

The incidence of the various outcomes of treatment for the directly followed up TB patients was compared with that of the indirectly followed up patients in the same period. The Chi-square test was used to compare percentages considering a significance level of 0.05 . The relative risk (RR) was used to evaluate the incidence of each type of treatment outcome between the two subgroups. Data were analyzed using EpiInfo software.

\footnotetext{
${ }^{k}$ Ministério da Saúde. Secretaria de Vigilância em Saúde. Departamento de DST, Aids e Hepatites Virais. Adesão ao tratamento antirretroviral no Brasil: coletânea de estudos do Projeto Atar: Projeto Atar. Brasília (DF); 2010. (Série B. Textos Básicos de Saúde). Available from: http:// www.aids.gov.br/sites/default/files/atar-web.pdf

${ }^{\prime}$ Holcman MM. Avaliação do efeito das perdas de seguimento nas análises feitas pelo estimulador produto-limite de Kaplan-Meier e pelo modelo de riscos proporcionais de Cox [thesis]. São Paulo (SP): Universidade de São Paulo; 2008.
} 
This study was approved by the Ethical Research Review Board at the Universidade Federal de Juiz de Fora (Opinion 166/2006) and the Fundação Hospitalar de Minas Gerais (Opinion 52/08). All participants signed a free and informed consent form.

\section{RESULTS}

Four reference centers treated $75.0 \%$ of the reported cases; $23.8 \%$ of these cases corresponded to patients who were not directly followed up because they were children aged $<2$ years $(n=9)$ or because they continued treatment in other health care units in the city $(n=81)$; therefore, their outcomes were indirectly followed up (Figure).

No significant differences were observed between the patients directly and indirectly monitored with regard to gender $(p=0.41)$, age $(p=0.75)$, race $(p=0.13)$, educational level $(p=0.47)$, HIV diagnosis $(p=0.11)$, and municipality of residence $(p=0.47)$. Among the 504 patients, $87.8 \%$ confirmed their residence in Juiz de Fora. Among the cases reported to SINAN, at least $13.8 \%$ (504) of the TB patients were coinfected with HIV (Table 1).

Among the directly followed up patients, $80.5 \%$ were new cases, $17.4 \%$ were relapsed or returned after defaulting on treatment, and $2.1 \%$ did not provide information regarding admission (Table 2).
Excessive and moderate alcohol consumption was reported for $25.1 \%$ and $22.0 \%$ of users, respectively; $29.6 \%$ never drank or did not drink in the previous year, and no information was available for $23.3 \%$. With regard to use of illegal drugs, $49.5 \%$ never used drugs, $16.0 \%$ were current users, $8.0 \%$ were former users, $4.9 \%$ had only experimented with drugs, and $21.6 \%$ did not provide information on consumption (Table 2).

In the outcomes of the prevalent cases, the incidence of treatment default and failure in the directly monitored subgroup was higher $(\mathrm{p}<0.05, \mathrm{RR}=5.72,95 \% \mathrm{CI}$ $2.65 ; 12.34)$ than that in the indirectly followed up subgroup $(\mathrm{RR}=8.31,95 \% \mathrm{CI} 1.08 ; 63.92)$. During the study period, the incidence of treatment default was $11.9 \%$ considering the 504 reported cases (53 among the directly followed-up patients and seven among the indirectly followed up patients), 16 of which were correctly reported to SINAN, and 44 were detected either by direct follow-up, were not acknowledged, or were placed under another classification in that system (Table 3 ). The 16 treatment defaults that were correctly notified represented $26.7 \%$ of the total number that would be evaluated (60) if the remaining 44 cases had been included.

The incidence of treatment default in the directly followed-up population remained higher $(p<0.01, R R=8.22,95 \%$ CI 2.99;22.58) for the outcomes of the new cases (Table 4).

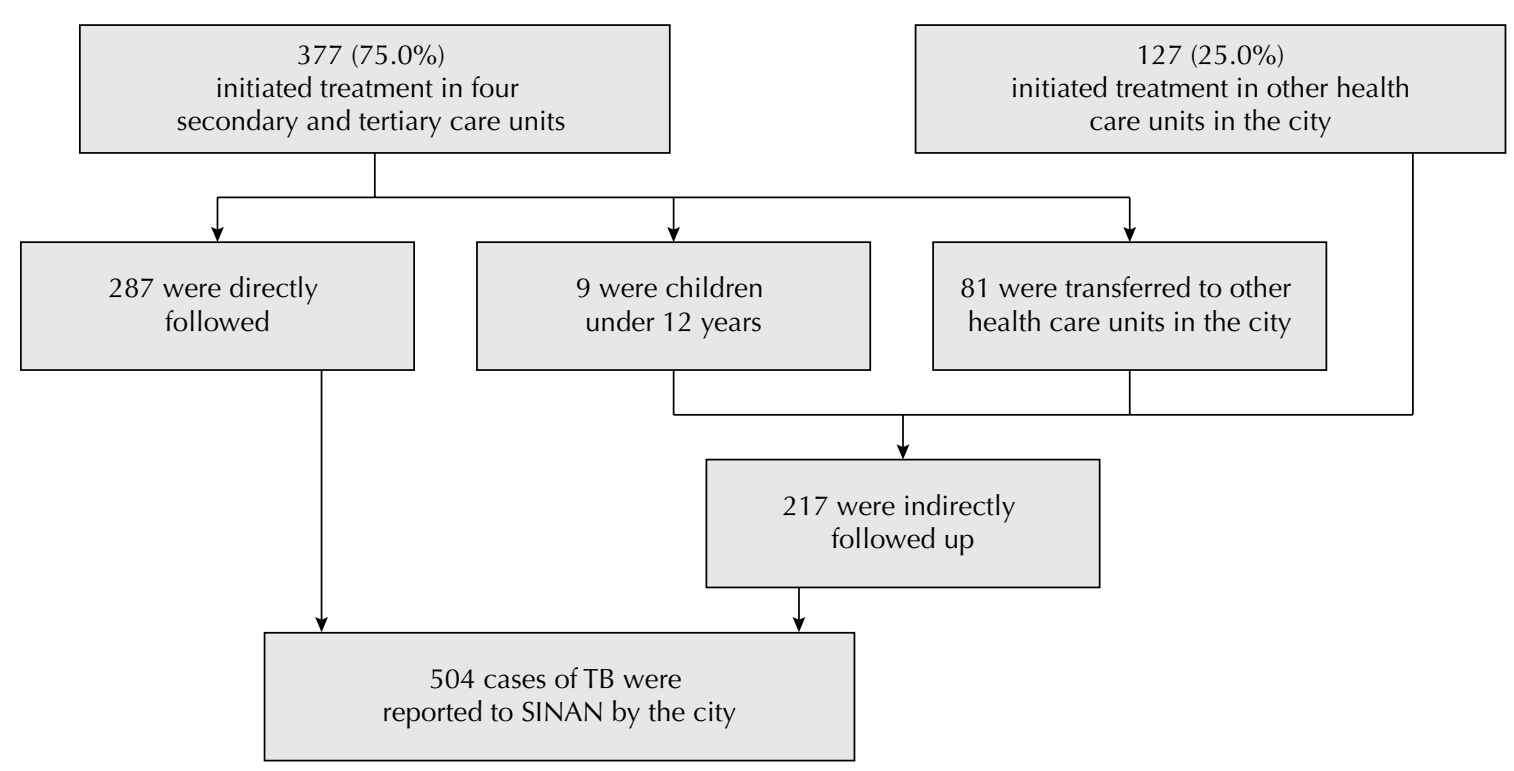

SINAN: Sistema Nacional de Agravos de Notificação (Information System for Reportable Diseases); TB: tuberculosis

Figure. Flowchart showing directly and indirectly followed up patients in relation to the total number of reported tuberculosis cases. Juiz de Fora, MG, Southeastern Brazil, 2008-2009. 
Table 1. Sociodemographic characteristics of the indirectly followed up $(\mathrm{N}=217)$ and directly followed up $(\mathrm{N}=287)$ populations. Juiz de Fora, MG, Southeastern Brazil, 2008-2009.

\begin{tabular}{|c|c|c|c|c|c|}
\hline \multirow{3}{*}{ Variable } & \multicolumn{4}{|c|}{ Follow-up } & \multirow{3}{*}{$\mathrm{p}$} \\
\hline & \multicolumn{2}{|c|}{ Indirect } & \multicolumn{2}{|c|}{ Direct } & \\
\hline & $\mathrm{n}$ & $\%$ & $\mathrm{n}$ & $\%$ & \\
\hline \multicolumn{6}{|l|}{ Gender } \\
\hline Male & 143 & $65.9^{a}$ & 200 & $69.7^{\mathrm{b}}$ & 0.41 \\
\hline Female & 74 & $34.1^{\mathrm{a}}$ & 87 & $30.3^{\mathrm{b}}$ & \\
\hline \multicolumn{6}{|l|}{ Age (years) } \\
\hline$\leq 38$ & 119 & $54.9^{a}$ & 150 & $52.3^{\mathrm{b}}$ & 0.75 \\
\hline$>38$ & 98 & $45.1^{\mathrm{a}}$ & 133 & $46.3^{b}$ & \\
\hline Incomplete ${ }^{c}$ & 0 & $0.0^{\mathrm{a}}$ & 4 & $1.4^{\mathrm{b}}$ & \\
\hline \multicolumn{6}{|l|}{ Race } \\
\hline White & 70 & $32.3^{\mathrm{a}}$ & 74 & $25.8^{\mathrm{a}}$ & 0.13 \\
\hline Black/Mixed & 80 & $36.8^{\mathrm{a}}$ & 120 & $41.8^{\mathrm{a}}$ & \\
\hline Incomplete data ${ }^{c}$ & 67 & $30.9^{a}$ & 93 & $32.4^{\mathrm{a}}$ & \\
\hline \multicolumn{6}{|l|}{ Educational level } \\
\hline None to complete primary school & 87 & $40.0^{\mathrm{a}}$ & 168 & $58.5^{\mathrm{b}}$ & 0.47 \\
\hline $\begin{array}{l}\text { High school to complete college } \\
\text { education }\end{array}$ & 44 & $20.3^{\mathrm{a}}$ & 70 & $24.4^{\mathrm{b}}$ & \\
\hline Incomplete data ${ }^{c}$ & 86 & $39.7^{\mathrm{a}}$ & 49 & $17.1^{\mathrm{b}}$ & \\
\hline \multicolumn{6}{|l|}{ HIV diagnosis } \\
\hline Positive & 40 & $18.4^{\mathrm{a}}$ & 30 & $10.4^{\mathrm{b}}$ & 0.11 \\
\hline Negative & 134 & $61.7^{\mathrm{a}}$ & 158 & $55.1^{\mathrm{b}}$ & \\
\hline Testing not conducted ${ }^{\mathrm{c}}$ & 35 & $16.2^{\mathrm{a}}$ & 89 & $31.0^{\mathrm{b}}$ & \\
\hline In process & 8 & $3.7^{\mathrm{a}}$ & 10 & $3.5^{\mathrm{b}}$ & \\
\hline \multicolumn{6}{|l|}{ City of residence } \\
\hline Juiz de Fora & 196 & $90.3^{\mathrm{a}}$ & 247 & $86.1^{\mathrm{b}}$ & 0.47 \\
\hline Others & 21 & $9.7^{\mathrm{a}}$ & 34 & $11.8^{\mathrm{b}}$ & \\
\hline Not informed ${ }^{c}$ & 0 & $0.0^{\mathrm{a}}$ & 6 & $2.1^{\mathrm{b}}$ & \\
\hline
\end{tabular}

a Source: City Department of Epidemiology/Sistema Nacional de Agravos de Notificação (SINAN - National System of Reportable Diseases).

b Source: Interview or direct observation of medical records (HIV diagnosis).

${ }^{c}$ For the Chi-square test, incomplete data or incomplete testing were not considered.

\section{DISCUSSION}

The results indicate at least two situations which are a cause for concern for TB control in a priority city: the neglect of data related to treatment default and failure reported to SINAN by the city, and the high percentage of TB treatment in secondary and tertiary care centers.

The main explanation for the differences in the incidence of treatment outcomes (treatment default and failure) in both subpopulations lies in the way of following up outcomes (detection method), considering that the two subpopulations were similar in many aspects. Direct follow-ups led to more careful assessment of outcomes, a hypothesis corroborated by the lower incidence of incomplete data found in this subgroup. On the other hand, the data on treatment outcomes obtained for the indirectly followed up patients, because of the increased probability of error in the municipal data surveillance services, may be biased owing to data misclassification, or omission in the registration of certain events, including treatment default. Therefore, $R R$ should be interpreted as a ratio of the incidence of treatment outcomes detected by either follow-up method.

Quality failures in the TB information system were observed in other studies that indicated underreporting of deaths involving TB and TB cases $^{6,15,20}$ as well as incomplete data. ${ }^{9}, 13,15,19$

A major limitation for the treatment and cure of TB is treatment default, which results in increased cost of treatment, increased rates of mortality and disease recurrence, and promotes the selection of resistant 
Table 2. Clinical and epidemiological characteristics of the directly followed up population. Juiz de Fora, MG, Southeastern Brazil, 2008-2009. ${ }^{\text {a }}(\mathrm{N}=287)$

\begin{tabular}{|c|c|c|}
\hline Characteristic & $\mathrm{n}$ & $\%$ \\
\hline \multicolumn{3}{|l|}{ Reference center } \\
\hline Center $1^{\mathrm{b}}$ & 118 & 41.2 \\
\hline Center $2^{\mathrm{c}}$ & 2 & 0.7 \\
\hline Center $3^{\mathrm{d}}$ & 129 & 44.9 \\
\hline Center $4^{\mathrm{e}}$ & 15 & 5.2 \\
\hline Incomplete data & 23 & 8.0 \\
\hline \multicolumn{3}{|l|}{ Hospitalized at some stage of treatment } \\
\hline Yes & 178 & 62.0 \\
\hline No & 109 & 38.0 \\
\hline \multicolumn{3}{|l|}{ Means of entering the health care service } \\
\hline New case & 231 & 80.5 \\
\hline Relapse/readmission after treatment default & 50 & 17.4 \\
\hline Incomplete data & 6 & 2.1 \\
\hline \multicolumn{3}{|l|}{ Treatment scheme used } \\
\hline Scheme I - basic (RHZ) & 250 & 87.2 \\
\hline Scheme IR - reinforced (basic $+E$ ) & 19 & 6.7 \\
\hline Scheme II - meningoencephalic encephalitis & 1 & 0.3 \\
\hline Scheme III - treatment failure (SZEEt) & 3 & 1.0 \\
\hline Scheme for MDR & 1 & 0.3 \\
\hline Incomplete data & 13 & 4.5 \\
\hline \multicolumn{3}{|l|}{ Clinical presentation } \\
\hline Pulmonary & 231 & 80.5 \\
\hline Extrapulmonary & 49 & 17.1 \\
\hline Pulmonary and extrapulmonary & 7 & 2.4 \\
\hline \multicolumn{3}{|l|}{ Type of presumptive diagnosis } \\
\hline Positive smear (bacilloscopy) & 216 & 75.3 \\
\hline Positive culture & 17 & 5.9 \\
\hline Histopathological examination suggestive of TB & 52 & 18.1 \\
\hline Readmission with prior positive bacilloscopy & 2 & 0.7 \\
\hline \multicolumn{3}{|l|}{ Institutionalized } \\
\hline Yes (penitentiary, nursing home, shelters) & 27 & 9.4 \\
\hline No & 220 & 76.6 \\
\hline Incomplete data & 40 & 14.0 \\
\hline \multicolumn{3}{|l|}{ DOTS } \\
\hline Yes & 150 & 52.3 \\
\hline No & 113 & 39.4 \\
\hline Incomplete data & 24 & 8.3 \\
\hline \multicolumn{3}{|c|}{ Alcoholic beverages in the last year until the beginning of treatment } \\
\hline Excessive drinking (CAGE 3-4) & 72 & 25.1 \\
\hline Moderate drinking (CAGE 0-2) & 63 & 22.0 \\
\hline Never drank or did not drink in the last year & 85 & 29.6 \\
\hline Incomplete data & 67 & 23.3 \\
\hline \multicolumn{3}{|l|}{ Smoking history } \\
\hline Smokers & 109 & 38.0 \\
\hline Ex-smokers & 76 & 26.5 \\
\hline Never smoked & 52 & 18.1 \\
\hline Incomplete data & 50 & 17.4 \\
\hline
\end{tabular}


Continuation

\begin{tabular}{|c|c|c|}
\hline \multicolumn{3}{|l|}{ Use of illegal drugs } \\
\hline Current users & 46 & 16.0 \\
\hline Ex-users & 23 & 8.0 \\
\hline Only experimented & 14 & 4.9 \\
\hline Never used & 142 & 49.5 \\
\hline Incomplete data & 62 & 21.6 \\
\hline \multicolumn{3}{|l|}{ Marijuana use in the last year } \\
\hline Yes & 25 & 8.7 \\
\hline Never used or did not use in the last year & 196 & 68.3 \\
\hline Incomplete data & 66 & 23.0 \\
\hline \multicolumn{3}{|l|}{ Cocaine use in the last year } \\
\hline Yes & 23 & 8.0 \\
\hline Never used or did not use in the last year & 198 & 69.0 \\
\hline Incomplete data & 66 & 23.0 \\
\hline \multicolumn{3}{|l|}{ Crack use in the last year } \\
\hline Yes & 23 & 8.0 \\
\hline Never used or did not use in the last year & 199 & 69.4 \\
\hline Incomplete data & 65 & 22.6 \\
\hline \multicolumn{3}{|c|}{$\begin{array}{l}\text { RHZ: rifampin, isoniazid, pyrazinamide; E: ethambutol; SZEEt: streptomycin, pyrazinamide, ethambutol, ethionamide; MDR } \\
\text { multi-drug-resistant; DOTS: Directly Observed Treatment-Short Course (supervised treatment); CAGE: Cut down, Annoyed, } \\
\text { Guilt, Eye-opener } \\
\text { a Data obtained from interviews or direct observation of medical records, except data on DOTS, which were obtained from SINAN. } \\
\text { b Hospital (inpatients and outpatients). } \\
{ }^{c} \text { Hospital (inpatients). } \\
\text { d General outpatient unit in the Unified Health System. } \\
\text { e Outpatient unit specialized in the care of patients with HIV. }\end{array}$} \\
\hline
\end{tabular}

bacilli. ${ }^{16,22}$ Considering the treatment default rate reported to SINAN by the city $(3.2 \%)$, Juiz de Fora meets WHO recommended rate of $\leq 5.0 \%$. ${ }^{\mathrm{a}}$ However, if we consider the cases of treatment default in the directly followed up subgroup, the more realistic incidence rate increases to $11.9 \%$, exceeding WHO's recommendation. This rate, which is similar to the national average, ${ }^{1, a}$ was neglected when considering the data reported to SINAN by the city of Juiz de Fora.

A cure should be attempted for $85.0 \%$ of the new TB cases in accordance with WHO international goals, which were adopted by the Brazilian government. ${ }^{a}$ Juiz de Fora has reached this goal considering the total number of reported cases and for the indirectly monitored subgroup with new TB cases treated in the period. On the other hand, this goal was below that of the directly followed up subgroup.

Previous studies ${ }^{2,15,20,22}$ have shown deficiencies in the quality of the information system, and consequently, in the data. Underreporting/incompleteness of data on TB cases and treatment outcomes sent to SINAN limits the understanding of the real epidemiological status of TB and undermines the planning and assessment of programs targeted at controlling this disease..$^{3,12}$
Considering the significant rate of treatment default that was neglected in the data sent to SINAN in this study, some practical questions should be raised: What happened to the neglected patients who defaulted on their treatment? Who are they? What were their clinical outcomes? Were they reincorporated into the health care system or remained neglected? Failure in the flow of information was also observed. Among the directly monitored patients, there was at least one patient who defaulted on treatment several times and subsequently died. However, this patient was registered as cured in the SINAN database. This and similar cases underscore the need to compare the incidence of directly detected treatment outcomes with those detected passively.

PNCT advocates the decentralization of APS activities, which should occur along with the strengthening of basic health units to achieve a level of quality compatible with TB program requirements. This would facilitate user access to treatment and would promote higher rates of adherence and cure. ${ }^{\mathrm{e}}$ The concentration of treatments in four secondary and tertiary care units showed that health care decentralization was not a widespread reality in Juiz de Fora in the study period. This disease requires municipalities to consider the external factors (social, environmental) that are outside the scope of 
Table 3. Comparison of outcomes of the prevalent cases of tuberculosis between directly followed up and indirectly followed up patients. Juiz de Fora, MG, Southeastern Brazil, 2008-2009.

\begin{tabular}{|c|c|c|c|c|c|c|c|c|c|}
\hline \multirow{3}{*}{ Outcome } & & & \multicolumn{4}{|c|}{ Follow-up } & \multirow{3}{*}{ Relative Risk } & \multirow{3}{*}{$95 \% \mathrm{Cl}$} & \multirow{3}{*}{$\mathrm{p}$} \\
\hline & \multicolumn{2}{|c|}{ SINAN ${ }^{a}$} & \multicolumn{2}{|c|}{ Indirect } & \multicolumn{2}{|c|}{ Direct } & & & \\
\hline & $\mathrm{n}$ & $\%$ & $\mathrm{n}$ & $\%$ & $\mathrm{n}$ & $\%$ & & & \\
\hline Cure & 418 & 82.9 & 180 & 82.9 & 172 & $59.9^{\mathrm{b}}$ & 1.38 & $1.23 ; 1.54$ & $<0.001$ \\
\hline Treatment default & 16 & 3.2 & 7 & $3.2^{\mathrm{b}}$ & 53 & 18.5 & 5.72 & $2.65 ; 12.34$ & $<0.001$ \\
\hline Deaths & 42 & 8.3 & 18 & 8.3 & 22 & $7.7^{\mathrm{b}}$ & 1.08 & $0.59 ; 1.96$ & 0.92 \\
\hline Transfer & 3 & 0.6 & 1 & $0.5^{\mathrm{b}}$ & 23 & 8.0 & 17.39 & $2.36 ; 127.8$ & $<0.05$ \\
\hline Failure & 3 & 0.6 & 1 & $0.5^{\mathrm{b}}$ & 11 & 3.8 & 8.31 & $1.08 ; 63.92$ & $<0.05$ \\
\hline Incomplete data & 22 & 4.4 & 10 & 4.6 & 6 & $2.1^{\mathrm{b}}$ & 2.20 & $0.81 ; 5.97$ & 0.18 \\
\hline Total & 504 & 100 & 217 & 100 & 287 & 100 & & & \\
\hline
\end{tabular}

${ }^{a}$ Notifications to the Sistema Nacional de Agravos de Notificação (SINAN - Information System for Reportable Diseases).

${ }^{\mathrm{b}}$ Denominator of relative risk (subgroup of reference).

Table 4. Comparison of outcomes of the incident cases of tuberculosis between directly and indirectly followed up patients. Juiz de Fora, MG, Southeastern Brazil, 2008-2009.

\begin{tabular}{|c|c|c|c|c|c|c|c|c|c|}
\hline \multirow{3}{*}{ Closures } & & & \multicolumn{4}{|c|}{ Follow-up } & \multirow{3}{*}{ Relative Risk } & \multirow{3}{*}{$95 \% \mathrm{Cl}$} & \multirow{3}{*}{$\mathrm{p}$} \\
\hline & \multicolumn{2}{|c|}{ SINAN ${ }^{a}$} & \multicolumn{2}{|c|}{ Indirect } & \multicolumn{2}{|c|}{ Direct } & & & \\
\hline & $\mathrm{n}$ & $\%$ & $\mathrm{n}$ & $\%$ & $\mathrm{n}$ & $\%$ & & & \\
\hline Cure & 362 & 86.1 & 164 & 86.3 & 152 & $65.8^{\mathrm{b}}$ & 1.31 & $1.17 ; 1.46$ & $<0.001$ \\
\hline Treatment default & 9 & 2.1 & 4 & $2.1^{\mathrm{b}}$ & 40 & 17.3 & 8.22 & $2.99 ; 22.58$ & $<0.001$ \\
\hline Deaths & 31 & 7.3 & 14 & 7.4 & 17 & $7.3^{\mathrm{b}}$ & 1.00 & $0.50 ; 1.97$ & 0.85 \\
\hline Transfer & 3 & 0.7 & 1 & $0.5^{\mathrm{b}}$ & 12 & 5.2 & 9.87 & $1.29 ; 75.21$ & $<0.05$ \\
\hline Failure & 0 & 0.0 & 0 & $0.0^{\mathrm{b}}$ & 5 & 2.2 & 9.05 & $0.50 ; 162.7^{c}$ & 0.09 \\
\hline Incomplete data & 16 & 3.8 & 7 & 3.7 & 5 & $2.2^{\mathrm{b}}$ & 1.70 & $0.54 ; 5.27$ & 0.52 \\
\hline Total & 421 & 100 & 190 & 100 & 231 & 100 & & & \\
\hline
\end{tabular}

a Notifications to the Sistema Nacional de Agravos de Notificação (SINAN - Information System for Reportable Diseases).

${ }^{\mathrm{b}}$ Denominator of relative risk (subgroup of reference).

c Estimated value using Haldane's correction.

the APS but can impact treatment outcomes. The rates of drug, alcohol, and cigarette use were high among the directly followed up patients and could partially explain the high rates of treatment default. Alcoholism and smoking may worsen the clinical presentation of TB and jeopardize its treatment regimen., ${ }^{3,17}$

The highest incidence of TB occurred among men, as observed in other studies. ${ }^{1,29}$ The difference in the incidence of TB between genders can be caused by economic, cultural, and social factors related to exposure. There was a higher frequency of TB cases among patients of black and mixed race. With regard to the white population, a previous study found that the risk of death from tuberculosis was 1.9 times greater for individuals of mixed race and 2.5 times greater for black individuals. ${ }^{\mathrm{m}}$ Low individual and household per capita income level, specifically for populations of black and mixed ethnicity, restricts the individual and social freedoms of these subjects and leads to deficiencies, stress, and poor health conditions in their surroundings.

The patients' low educational level reflects a set of precarious socioeconomic determinants that can increase vulnerability to $\mathrm{TB}$ and account for the increased incidence of TB and increased treatment default rate. ${ }^{11,17,18}$

Despite the high rate of readmission and relapse after treatment default in the directly monitored population $(17.4 \%)$, a small percentage $(6.7 \%)$ made use of the reinforced scheme I. This may have therapeutic implications, such as the selection of antibiotic-resistant bacilli. This was the suitable scheme for patients undergoing retreatment, i.e., who had

m Ministério da Saúde. Secretaria Especial de Políticas de Promoção da Igualdade Racial - SEPPIR. Política Nacional de Saúde Integral da População Negra. Secretaria de Gestão Estratégica e Participativa. Brasília (DF); 2007. 
already been treated for more than 30 days in less than five years, or who needed a new treatment for recurrence after cure. ${ }^{\mathrm{n}}$

WHO has proposed DOTS as a global strategy to avoid treatment default and encourage adequate drug therapy. ${ }^{29}$ At least $52.3 \%$ of the patients received DOTS during the study period. However, this term may be overused and refer to any patient who has been hospitalized or directly followed up regardless of the follow-up period.

HIV-TB comorbidity constitutes a risk factor for treatment default of TB and HIV treatment. ${ }^{17,21,26,29}$ Drug interactions and adverse reactions in HIV-positive patients are more significant compared with the HIV-negative population. HIV infection predisposes individuals to a higher incidence of adverse effects, which leads to increased prioritization of treatments for AIDS in detriment of TB. ${ }^{21}$ Therefore, MS has stated that HIV testing is mandatory in cases of TB and vice versa. However, a high percentage $(24.6 \%)$ of patients with TB in the present study did not undergo serological testing for HIV. The rate of HIV testing among TB patients positive for HIV reported by the city (13.9\%) was similar to the average for Brazil in $2010 .^{\circ}$ However, this co-infection rate highlights the need for increased efforts to prevent its occurrence because it involves a "deadly combination". p

Some patients assisted in the four main reference centers could not be directly followed up owing to the difficulty in the obtaining of parental consent because they were aged $<12$ years. Others were not directly followed up because they continued treatment in other health care centers in the city. However, these patients were included in the indirectly followed up patient subgroup.
Data surveillance is an important responsibility of public health care services for the control of infectious diseases. However, the TB program has passively worked in various municipalities in Brazil. Accordingly, Belo Horizonte, another priority city in Minas Gerais, exhibited aspects of fragility in its TB surveillance program, such as inadequate active search for patients with respiratory symptoms, predominance of case notifications in reference centers, and incipient decentralization of TB control activities through the APS. ${ }^{7,18,23}$ Moreover, other studies have observed low rates of serological HIV testing and low sensitivity in detecting treatment outcomes resulting from multidrug resistance failure. ${ }^{4,14,23}$ These results corroborate the situation found in the present study, which should not be regarded as an isolated case because it has been repeated in several priority municipalities. This limitation demands a more systematic assessment on the part of the PNCT managers.

Some recommendations to health authorities involved in TB control at various levels of the Federation should be emphasized: (i) strengthening of the decentralization of TB control activities to health care units (ESF and basic health care units) with the aim to improve the effective use of DOTS, search for contacts, early detection of the disease, and the opportunities for treatment; (ii) establishment of a search routine in other information systems (Mortality Data System and TB Laboratory Data System) to improve the quality of data on the outcomes of TB cases; and (iii) evaluation of the TB surveillance system in the city and other priority cities in order to define guidelines and priorities to improve the indicators for cure, treatment default, and incidence of the disease.

\footnotetext{
${ }^{n}$ Ministério da Saúde. Sociedade Brasileira de Pneumologia e Tisiologia. Controle da tuberculose: uma proposta de integração ensino -serviço.

5. ed. Rio de Janeiro: FUNASA; 2002.

- Ministério da Saúde. Portal da Saúde. Ministério da Saúde é reconhecido pelo controle da tuberculose. Doenças Negligenciadas. Brasília (DF); 2012 [cited 2013 Jun 10]. Available from: http://portalsaude.saude.gov.br/index.php/profissional-e-gestor/vigilancia/linksvigilancia?start $=560$

p Guércio PMS. Epidemiologia da AIDS em Juiz de Fora - 2009. Juiz de Fora: Secretaria de Saúde; 2009 [cited 2013 Jul 27$]$. Available from: http://www.pjf.mg.gov.br/secretarias/saude/aids_dst/historia.php
} 


\section{REFERENCES}

1. Belo MTCT, Luiz RR, Hanson C, Selig L, Teixeira EG, Chalfoun T, et al. Tuberculose e gênero em um município prioritário no estado do Rio de Janeiro. J Bras Pneumol. 2010;36(5):621-5. DOI:10.1590/S1806-37132010000500015

2. Bierrenbach $A L$, Stevens $A P$, Gomes $A B F$, Noronha EF, Glatt R, Carvalho $\mathrm{CN}$, et al. Efeito da remoção de notificações repetidas sobre a incidência da tuberculose no Brasil. Rev Saude Publica. 2007;41(Suppl 1):67-76. DOI:10.1590/S0034-89102007000800010

3. Braga JU. Vigilância epidemiológica e o sistema de informação da tuberculose no Brasil, 2001-2003. Rev Saude Publica. 2007;41(Suppl 1):S77-88. DOI:10.1590/S0034-89102007000800011

4. Dalcolmo MP, Andrade MKN, Picon PD. Tuberculose multirresistente no Brasil: histórico e medidas de controle. Rev Saude Publica. 2007;41(Suppl1):34-42. DOI:10.1590/S0034-89102007000800006

5. Ewing JA. Detecting alcoholism. The CAGE questionnaire. JAMA. 1984;252(14):1905-7. DOI:10.1001/jama.1984.03350140051025

6. Façanha MC. Tuberculose: subnotificação de casos que evoluíram para o óbito em FortalezaCE. Rev Bras Epidemiol. 2005;8(1):25-30. DOI:10.1590/S1415-790X2005000100004

7. Froes GC, Coutinho RL, Avila MN, Cançado LR, Miranda SS. Perfil e seguimento dos pacientes portadores de Mycobacterium SP do Hospital das Clínicas da Universidade Federal de Minas Gerais. J Pneumol. 2003;29(6):365-70. DOI:10.1590/S0102-35862003000600008

8. Guimaraes MDC, Oliveira HN, Campos LN, Santos CA, Gomes CE, Oliveira SB, et al. Reliability and validity of a questionnaire on vulnerability to sexually transmitted infections among adults with chronic mental illness: PESSOAS Project. Rev Bras Psiquiatr. 2008;30(1):55-9. DOI:10.1590/S1516-44462008005000005

9. Malhão TA, Oliveira GP, Codennoti SB, Moherdaui F. Avaliação da completitude do Sistema de Informação de Agravos de Notificação da Tuberculose, Brasil, 2001-2006. Epidemiol Serv Saude. 2010;19(3):245-56.

10. Marques M, Gazola LH, Cheade MFM. Avaliação do SINAN na detecção de co-infecção TB-HIV em Campo Grande, MS. Bol Pneumol Sanit. 2006;14(3):135-40.

11. Maruza M, Albuquerque MFPM, Coimbra I, Moura LV, Montarroyos UR, Miranda Filho DB, et al. Risk factors for default from tuberculosis treatment in HIV-infected individuals in the state of Pernambuco, Brazil: a prospective cohort study. BMC Infect Dis. 2011;11:351. DOI:10.1186/1471-2334-11-351

12. Medeiros D, Sucupira ED, Guedes RM, Costa AJ. Análise da qualidade das informações sobre tuberculose no município de Belford Roxo, Rio de Janeiro, 2006 a 2008. Cad Saude Coletiva. 2012;20(2):146-52.

13. Moreira CMM, Maciel ELN. Completude dos dados do programa de controle da tuberculose no Sistema de Informação de Agravos de Notificação no Estado do Espírito Santo, Brasil: uma análise do período de 2001 a 2005. J Bras Pneumol. 2008;34(4):225-9. DOI:10.1590/S1806-37132008000400007

14. Muniz JN, Palha PF, Monroe AA, Gonzales RC, Ruffino Netto A, Villa TCS. A incorporação da busca ativa de sintomáticos respiratórios para o controle da tuberculose na prática do agente comunitário de saúde. Cienc Saude Coletiva. 2005;10(2):315-21. DOI:10.1590/S1413-81232005000200009

15. Oliveira GP, Pinheiro RS, Coeli CM, Barreira D, Codenotti SB. Uso do sistema de informação sobre mortalidade para identificar subnotificação de casos de tuberculose no Brasil. Rev Bras Epidemiol. 2012;15(3):468-77. DOI:10.1590/S1415-790X2012000300003

16. Oliveira HB, Moreira Filho DC. Abandono de tratamento e recidiva da tuberculose: aspectos de episódios prévios, Campinas, SP, Brasil, 1993-1994. Rev Saude Publica. 2000;34(5):437-43. DOI:10.1590/S0034-89102000000500002

17. Orofino IRL, Brasil PEA, Trajman A, Schmaltz CAS, Dalcolmo M, Rolla VC. Preceptores dos desfechos do tratamento da tuberculose. J Bras Pneumol. 2012;38(1):88-97. DOI:10.1590/S1806-37132012000100013

18. Paixão LMM, Gontijo ED. Perfil de casos de tuberculose notificados e fatores associados ao abandono, Belo Horizonte, MG. Rev Saude Publica. 2007;41(2):205-13. DOI:10.1590/S0034-89102007000200006

19. Pillaye J, Clarke A. An evaluation of completeness of tuberculosis notification in the United Kingdom. BMC Public Health. 2003;3:31. DOI:10.1186/1471-2458-3-31

20. Pinheiro RS, Andrade VL, Oliveira GP. Subnotificação da tuberculose no Sistema de Informação de Agravos de Notificação (SINAN): abandono primário de bacilíferos e captação de casos em outras fontes de informação usando linkage probabilístico. Cad Saude Publica. 2012;28(8):1559-68. DOI:10.1590/S0102-311X2012000800014

21. Rodrigues ILA, Monteiro LL, Pacheco RHB, Silva SED. Abandono do tratamento de tuberculose em coinfectados TB/HIV. Rev EsC Enferm USP. 2010;44(2):383-7. DOI:10.1590/S0080-62342010000200020

22. Santos J. Resposta brasileira ao controle da tuberculose. Rev Saude Publica. 2007;41(Suppl 1):89-94. DOI:10.1590/S0034-89102007000800012

23. Silva HO, Gonçalves MLC. Coinfecção tuberculose e HIV nas capitais brasileiras: observações a partir dos dados do sistema de informação de agravos de notificação. Rev Bras Prom Saude. 2009;22(3):172-8. DOI:10.5020/18061230.2009.p172

24. Silva MR, Mota PMPC, Leite RMH, Lobato FCF, Leite RC, Lage AP. Evaluation of adenosine deaminase seric activity in the diagnosis of bovine tuberculosis. Mem Inst Oswaldo Cruz. 2006;101(4):391-5. DOI:10.1590/S0074-02762006000400008 
25. Silva MR, Rocha AS, Costa RR, Alencar AP, Oliveira $\mathrm{VM}$, Fonseca Jr AA, et al. Tuberculosis patients co-infected with Mycobacterium bovis and Mycobacterium tuberculosis in an urban area of Brazil. Mem Inst Oswaldo Cruz. 2013;108(3):321-7. DOI:10.1590/S0074-02762013000300010

26. Silveira CS, Passos PT, Soder TCH, Machado CPH, Fanfa LS, Carneiro M, et al. Perfil epidemiológico dos pacientes que abandonaram o tratamento para tuberculose em um município prioritário do Rio Grande do Sul. Rev Epidemiol Control Infect. 2012;2(2):46-50.

27. Teixeira HC, Abramo C, Munk ME. Diagnóstico imunológico da tuberculose: problemas e estratégias para o sucesso. J Bras Pneumol. 2007;33(3):323-34.

DOI:10.1590/S1806-37132007000300015

28. Trigueiro JVS, Nogueira JA, Sá LD, Palha PF, Villa TCS, Trigueiro DRSG. Controle da tuberculose: descentralização, planejamento local e especificidades gerenciais. Rev Latino-Am Enfermagem. 2011;19(6):1-8. DOI:10.1590/S0104-11692011000600003

29. Vieira AA, Ribeiro SA. Abandono do tratamento de tuberculose utilizando-se as estratégias tratamento auto-administrado ou tratamento supervisionado no Programa Municipal de Carapicuíba, São Paulo, Brasil. J Bras Pneumol. 2008;34(3):159-66. DOI:10.1590/S1806-37132008000300006

Research supported by the Conselho Nacional de Desenvolvimento Científico e Tecnológico (CNPq - through the call for projects on neglected diseases - Process 410595/2006-3).

Based on the master's thesis of Pereira LC, titled: "Fatores associados ao abandono do tratamento da tuberculose em um município prioritário do Brasil: um estudo de coorte", presented to the Universidade Federal de Juiz de Fora in 2014. The authors declare no conflict of interest. 